He was the designer of the widely used 'Harrison restorer'. The recipient of the medal delivers the Harrison Memorial lecture before the Society, a lecture which need not - and as time passes cannotdeal with Harrison himself or his work. The medal this year has been awarded to Mr. Bernard Howard, a vice-president of the Institute of Chemistry, who took as the subject of his lecture delivered on December 12, "Cinchona and Civilisation". Mr. Howard is a director of one of the largest manufacturers of quinine in Great Britain, whose records go back into the early years of the last century, and he was able to illustrate his discussion, in his presentation of theproblem of man's fight against malaria, from the records of his own firm.

WHEN the British army from Bulgaria landed in the Crimea in 1857, the troops were so weak from the effects of malaria that they were searcely able to carry their equipment. Presumably in 1857, quinine was regularly administered by army doctors to malaria patients, but Mr. Howard maintains that it is almost certain that there was no systematic method of prophylaxis at that time. From an examination of the records of his firm, he finds that the output for 1857 shows an increase of 27 per cent over the 1856 figure, while the post-Crimean War year, 1858, shows a decrease of 22 per cent. $\mathrm{He}$ assumes that a good proportion of the 1857 increase must have gone to the army, and that the fact that there was any army at all to be landed in the Crimea was due to the use of quinine. The first cinchona trees known to be grown in Great Britain were in the garden of the Society of Apothecaries in London, maintained to this day as the Chelsea Physic Gardon. There is a record in Evelyn's Diary of his seeing cinchona trees there. At a site in Tottenham, which is now an arterial road, the Howard family grew cinchona in the early nineteenth century, and quinine was extracted experimentally from these trees. So early as 1823 it was being manufactured on a large scale in Great Britain, although from imported bark.

\section{Exhibition of Microscopes}

Messrs. W. Watson and Sons, Ltd., 313 High Holborn, London, W.C.1, have an exhibition of microscopes at the Central Hall, Westminster, London, S.W.1, with the view of popularising the use of the microscope and demonstrating its recreational and educational possibilities. In this connexion, several small microscopes are exhibited, the cost of which is very reasonable. The material set up shows clearly that a great deal of useful teaching work can be done with a comparatively simple instrument. Striking exhibits of differential illumination by means of Rheinberg's disc illustrate the advantages of this method for demonstration and elementary teaching purposes. A very useful instrument exhibited, which should appeal to all microscopists and naturalists who are interested in microscopy in the field, is a small portable microscope. The stand can be folded and the tube lowered so that the whole instrument may be reduced to a size of 7 in. $\times 3$ in. $\times 3$ in. The cost too is very reasonable. Among the demonstrations in photomicrography is one by the Kodak Co., in which experiments with a microscope and an ordinary Brownie 12s. $6 d$. box camera, using a super-sensitive panchromatic plate, have produced excellent results. Several new departures for methods in metallurgy and microprojection are being exhibited. A number of useful changes in construction of, and additions to, microscopes for research in biology, crystallography, metallurgy, are also on view; several types of binocular microscope, one with a new inter-pupillary adjustment, being of particular interest. The exhibition, which is open until December 16 , is well worth a visit not only by microscopists, who wish to know what can be done with a simple instrument and the recent developments in the finer instruments; but also by those not familiar with microscope work, since there is much of interest to be learned from it.

\section{Racial Elements in India}

ON November 17, Dr. J. H. Hutton, the Indian Census Commissioner, gave a lecture, which is now available, before the Royal Society of Arts (J.Roy. Soc. Arts, 82, No. 4226). Summarising the results of his work, Dr. Hutton discussed the racial elements in the population of India at length, analysing it into no less than six distinct strains. To a Negrito (Andamanese) sub-stratum must be added a race of Australoid affinities, which is "widely spread" in India. Thirdly, an immigration of Austro-Asiatic speaking peoples can be traced from the Punjab hills to the Bay of Bengal. Fourthly came the Dravidian speaking pooples, described by Dr. Hutton as "Mediterranean" and "Armenoid", from Mesopotamia. Fifthly and sixthly, Dr. Hutton associates Indian brachycephaly with an Aryan speaking stock, described as "Alpine" and said to have preceded the true Aryans. At the conclusion, Mr. K. de B. Codrington pointed out that Dr. Hutton's analysis was based almost entirely on linguistic evidence. No craniometrical evidence can be brought forward in support of the suggested Negrito strain, nor is a widely spread Australoid type discernible. Brachycephaly cannot be seized upon as an isolated fact and labelled Alpine. Furthermore, Harrower's opinion, that there is no support for the identification of the Dravidian and Mediterranean types, should be given serious attention. In putting forward such theories, the canons of biological thought must be obeyed, and due consideration given to current anthropometrical opinion.

\section{Jericho}

Prof. John Garstang's survey of the results of his excavations at Jericho in his article in the Times of December 6, following on his lecture at the University of Liverpool on November 17, affords a consecu. tive story of the history of the city which it is possible to accept with assurance in the light of the excavations of last season. Among the more interesting features are the evidence of Babylonian influence in the Early Bronze Age and the conspicuous rarity of Cretan and Mycenæan motives under the eighteenth 
dynasty when they might be expected. Four separate and distinct defensive systems have been differen. tiated, of which the earliest, belonging to the Early Bronze Age (c. 2500-2100 B.c.) rested on deposits of a still older period. The period of the city's greatest expansion was in the third phase (Middle Bronze Age II), which is marked by a cultural change. Under the Hyksos at that time, the city walls were much extended; and the character of the Palace and other buildings suggests that Jericho, as the residence of a Hyksos governor, had become a city of more than local importance. This phase comes to an end at about 1600 B.c. when the city was destroyed, presumably by the Pharaohs. It was rebuilt, but restricted within the bounds of the earlier area of occupation. From that time onward its history can be traced by means of scarabs and painted pottery having a range of dates between 1600 and 1400 B.c. At the latter date under Amenophis III the normal life of the city ceases abruptly. All the buildings of the Palace area and the few houses against the city wall bear witness to a great catastrophe-the indications are an earthquakefollowed by an intense fire while the rooms were in occupation. Thenceforward until about 900 в.c. the site was practically deserted.

\section{Sixth International Congress for Scientific Management}

Considerable progress is being made with the organisation of the Sixth International Congress for Scientific Management, which is to be held in London on July 15-18, 1935. A strong council which includes representatives of societies connected with various phases of scientific management has been formed. H.R.H. the Prince of Wales is the patron of the Conference and Government support has been promised. The chairman is Sir George Beharrell, managing director of Dunlops. The chairmen of the various committees are Dr. E. F. Armstrong (Organisation), Sir Henry Fowler (Technical) and Mr. G. R. Freeman (Finance). Mr. H. Ward, formerly general secretary of the National Institute of Industrial Psychology, has been appointed secretary. It is hoped that the Congress will demonstrate that British industry and British technicians are fully alive to the importance of scientific principles in management. Many highly skilled organisations exist, which are using and propagating these principles, but the Congress should help still further to stimulate the national movement in this direction and to create a general appreciation of the applications of management to organised industrial and commercial activity. Among the questions which will be discussed are: concrete examples of the application of scientific management to distribution problems in manufacturing, wholesaling and retailing; methods of controlling production; methods of selection, education and training of personnel suitable for high administrative positions; correct methods of inculcating modern management principles and practices in large-scale, medium and small undertakings, and the rôle of trade or other associations in this field.

\section{Glass-Making}

THE Friday evening discourse at the Royal Institution on December 8 was delivered 'Ny Major R. M. Weeks, a director of Messrs. Pilkington Brothers, Ltd., on "The Making of a Sheet of Glass". Major Weeks first gave a brief outline of some fundamental scientific considerations, with special reference to composition, the tendency to devitrify, and the resistance of the product to weathering. Melting is carried out by one of two processes, namely, the older method in which the raw materials are placed in pots in a gas-fired furnace, and the modern method by which the raw materials are introduced at one end of a continuous furnace and the molten glașs withdrawn at the other. The various processes necessary for the manufacture of sheet and plateglass were described in detail. Films were shown of the hand-blown and the machine.drawn cylinder sheet glass processes. The latter has been superseded by the flat-drawn process, in which the sheet is drawn in the form of a flat continuous ribbon. To illustrate the manufacture of plate glass, an interesting film of the Bicheroux casting process was shown and reference was made to the latest process of plate glass manufacture, the flow process, in which the molten glass is delivered to rollers which form a continuous ribbon of glass. In the modern continuous grinding and polishing machine the glass plates, laid on a moving bed, pass successively under the grinding and polishing machines. The discourse concluded with a description of two novel forms of flat glass of interest, namely, opaque glass manufactured in black, white and various colours and known as vitrolite; and toughened glass, known as 'armourplate' or 'triplex toughened', which has a high resistance to fracture combined with the property, if broken, of shattering into small harmless fragments.

\section{India and Displaced German Scientific Workers}

Although the creation of special posts and the raising of supplementary funds for research work have alleviated in some degree the difficulties attendant on the absorption of displaced German Jewish teachers and students, these measures have not been adequate to provide for all, or to meet all contingencies. In India, where the appeal on behalf of the displaced workers has met with a sympathetic reception in certain quarters, the posts which might be made available are extremely limited in number, and in the matter of academic and research appointments, India has its own special difficulties which militate against even limited assistance. In each year India produces a relatively large number of men trained in science, including many with qualifications obtained in Europe. In present conditions these find difficulty in obtaining appointments in India. In an interview with Acharya Roy, which appears in the Amrita Bazar Patrika of November 14, relating to the appeal on behalf of Jewish men of science, reference is made to the virtual monopoly enjoyed by Europeans in posts for scientific research in India, against which Indian research students have made way only very slowly in the last fifteen ycars. Acharya Roy points 